\title{
Attitudes of managers in the Iraqi Kurdistan region private banks towards the impact of knowledge management on organizational effectiveness
}

\author{
Zana Majed Sadq ${ }^{a, b}$, Bestoon Othman ${ }^{c^{*}}$ and Hazhar Omer Mohammed
}

${ }^{a}$ Department of Management and Accounting, Faculty of Humanities and social science Koya University, Koya KOY45, Kurdistan Region - F.R. Iraq

${ }^{b}$ Department of Legal Administration, Collage of Business and Economics, Lebanese-French University, Kurdistan Region - F.R. Iraq ${ }^{c}$ Department of Business Administration, Koya Technical Institute, Erbil Polytechnic University, Iraq

\section{H R O N I C L E}

\section{Article history:}

Received: October 9, 2019

Received in revised format: November 252019

Accepted: December 27, 2019

Available online:

December 27, 2019

Keywords:

Knowledge management

Knowledge creation

Storage knowledge

Knowledge sharing

Knowledge application

Technology knowledge

Organizational effectiveness

\section{A B S T R A C T}

This study aims to identify the impact of knowledge management through its dimensions; namely knowledge creation, storage knowledge, knowledge sharing, knowledge application and technology knowledge on organizational effectiveness based on the managers' attitudes in private banks in the Erbil city in Kurdistan region, Iraq. To achieve the study objectives, a questionnaire was constructed consisting of (40) questions distributed to a sample of (80) managers and supervisors, (76) of which were returned, while (69) were valid for statistical analysis. The main objective of this study is to design a default model and test in the study field in order to understand how managers can successfully implement the knowledge management to achieve the organizational effectiveness. The study found that knowledge management had an impact on organizational effectiveness according to the study samples perspectives. Based on the results, the study presents a set of recommendations regarding the knowledge management which most importantly the private banks should adopt in a logical sequence. This could contribute in achieving an organizational environment supportive of enabling an environment to the practice of radical changes.

C 2020 by the authors; licensee Growing Science, Canada

\section{Introduction}

The end of the last century saw great interest in the subject of knowledge and its impact on organizations. Knowledge is considered to be one of the main assets and it plays direct role for the success of organizations in a highly competitive environment and constant change. This requires the application of the concept of "knowledge management" because of its importance in achieving outstanding performance. Knowledge management is one of the new topics that has become a growing concern in the world of management and is being applied in various organizations (Song et al., 2006). Techniques for knowledge management need to be selected based on the purpose for which knowledge is "managed" (Norang, \& Nooshin, 2016). Knowledge management is the entrance for the development of contemporary organizations and enables them to build intellectual capital capable of meeting future challenges (Alavi et al., 2006). It is the processes of effective learning along with creating, organizing, and exchanging knowledge (Zhengwei et al., 2019). Many changes such as globalization, increasing the volume of world trade, increasing competition, and rapid transfer of capital have enhanced the role of knowledge management in achieving organizational efficiency and productivity to achieve competitive advantage (Sadq et al., 2018). The aim of knowledge management is to improve an organization's efficiency by using the knowledge resource properly (Jamil \& 
Lodhi, 2015). Akdere (2009) states that the role of knowledge management has become vital for the survival of the organization and serves as a strategic business function in the organization with its impact on human capital, teamwork, overall organizational performance, and organizational effectiveness. Significant differences have emerged in how the concept of knowledge management, its importance and its value are perceived. In developed societies, there is a greater interest in knowledge management and a better awareness as to how it can be exploited and distributed. However, in developing societies in general, there is a lack of attention, diligence and care towards knowledge management. Although knowledge is deemed a competitive main factor in the world economy, it is necessary to consider another significant factor: the customer, for effective involvement in the dynamic market at present (Arazpoor \& Meymand, 2016).

The private banks in the Kurdistan region of Iraq cannot live in isolation from it since they are affected by the changes around them and face the increasing demand for their services. These banks still suffer from the difficulty of practical linkage between the knowledge storage of human resources and the process of achieving organizational effectiveness. Organizational effectiveness is one of the most difficult tasks in the organizations because good management and leadership do not show its success simply after a decision has been made in difficult situations and crises. This study will examine the importance of using knowledge management in achieving organizational effectiveness as well as the extent to which knowledge management is used in private banks in the Kurdistan region of Iraq. The objective of this study is to describe the concept of "knowledge management" and its elements, objectives, and benefits. The significance of the study comes from the importance of the study topic "Knowledge Management" and its impact in different organizations, the achievement of excellence in performance, and the ability to compete in different environments.

\section{Literature review}

\subsection{Knowledge Management}

Knowledge management has been defined as a set of clear and well-defined approaches and processes aimed at discovering knowledge functions, both positive and negative in various types of processes. As well as managing them, identifying new products or strategies, strengthening human resource management, and achieving a number of other goals to be achieved (Wiig, 1993). Knowledge management is any sort of efforts made by managers to organize and build the organization's capital from information resource, or what may otherwise is called as the intellectual capital of the organization (Daft, 2007). It is the process of creating value from intangible assets in an organization (Ping et al., 2019). Knowledge management is a description of organizations' efforts to collect, store, and distribute knowledge (Segev, 2010). Ghomi and Barzinpour (2018) state that knowledge management emphasizes value creation, which implies the managing of current knowledge and its transformation into helpful organizational knowledge. Darling (1996) describes knowledge management as the processing of information and perceptions of individuals. It is information technology and it is interested in databases and information $(\mathrm{Bu}-$ kowits \& Williams, 2000). Knowledge management is the systematic and integrated process for coordinating the activities of the organization in the acquisition, creation, storage, participation, development and replication of knowledge by individuals and groups seeking to achieve the main organizational objectives (Muhammad et al., 2019). It is a comprehensive concept for all organizations' sections that focuses on the value of knowledge as shown in the results of knowledge management recognized in business models (Sadq et al., 2018). Knowledge management is the process of accumulating and generating knowledge efficiently, facilitating knowledge sharing and managing the foundation, so that it can be effectively applied in the organization (Turban, et al., 2004). It is effective management of information stored in the organization (Laudon \& Laudon, 2005). It is the process that facilitates knowledge sharing and establishes a process of continuous learning throughout the organization (Harun et al., 2019). It is the process of generating, acquiring, using and participating in knowledge effectively to enhance the organization's learning and improve its performance (Bishop, et al., 2008). Knowledge management is a thriving work generation system and learning environment that encourages the generation, collection, use, and reuse of both personal and organizational knowledge in pursuit of a new business value. It is an administrative activity that develops, stores, distributes, transfers, and applies knowledge, as well as its use and utilization to achieve organizational goals, decision-making, and problem solving, in order to achieve excellence and efficiency in the organization (Rao, 2012).

\subsection{Knowledge management objectives and benefits}

Knowledge management seeks to achieve the following things:

1. Contribute to raising the efficiency of performance and improve the quality of the product or service provided (Mathew, 2008),

2. Creates a positive environment that stimulates workers to innovate, releases their inherent knowledge and makes it available to the organization (Dalkir, 2005),

3. Seeks to find effective leadership with the capacity to build and apply knowledge management,

4. Empower employees and increase their abilities to perform their tasks efficiently and effectively. 


\subsection{Processes of Knowledge Management}

The processes of knowledge management can be identified as follows:

\subsubsection{Knowledge Creation}

It begins with an idea presented by knowledge makers through acquisition or innovation, and is one of the keys to the organization in the long term, as well as competing through the creation of new ideas (Bourdreau \& Couillard, 1999). It is the process of creating knowledge within an organization and acquiring new knowledge (Jashapara, 2004). It is an interaction between implicit and explicit knowledge through which new knowledge is created, derived and created within the organization to secure various types of knowledge for future decisions (Sadq et al., 2019). Explicit knowledge is a set of codified knowledge in the form of organizational manuals, documents and databases. However, implicit knowledge represents intangible knowledge such as the experience and perspectives of individuals (Manab \& Aziz, 2019).

\subsubsection{Knowledge Storage}

This is the process of organizing, collecting and storing data in certain ways so that they are easily accessible to employees. It includes all activities that preserve knowledge, allow them to stay in systems and tools, be updated and easily retrieved by the beneficiaries (Rao, 2012). The need for a knowledge base according to Turban (2001) is vital and determines the amount of open part of that base, and that the value of knowledge does not depend on the moment of generation, but on the remote value of knowledge, so the repositories of knowledge must be sustained. Storage of knowledge has become a significant process because knowledge is becoming increasingly invaluable. Furthermore, when individuals leave an organization for one reason or another, organizations face a significant risk resulting from knowledge loss. Knowledge storage, retention and protection are therefore significant elements, particularly for organizations suffering from high turnover (Albream \& Maraqa, 2019).

\subsubsection{Knowledge Sharing}

Knowledge sharing is the process of transferring knowledge to the employees who need it in time to perform essential tasks (Dalkir, 2005). Coakes (2003) mentioned that the process of sharing knowledge is the first step in the process of using knowledge, and is intended to deliver the right knowledge, to the right person at the right time, in an appropriate form and at an appropriate cost. Knowledge sharing can take place at the individual or organizational level. Employee-level sharing is to talk to coworkers to help them do things better, faster and more effectively. At the organization level, it refers to the creation, organization and reuse of knowledge and the transfer of knowledge based on existing expertise within the organization and making it available to other organizations (Lin, 2007). Sharing and transferring knowledge depend on the existence of efficient processes. For instance, reports, manuals, training, formal meetings and on-the-job or informal learning, for instance informal conferences, seminars and sessions that generally take place outside working hours (Albream \& Maraqa, 2019).

\subsubsection{Knowledge Application}

It includes using the knowledge in performing tasks such as problem solving, decision making, new idea generating and learning (Jamila \& Lodhib, 2015). It refers to making it more suitable for use in the implementation of organizational activities and more relevant to its tasks (Martins et al., 2001). The purpose of knowledge management is to apply the knowledge available to the organization, the process of practice and the actual use of the knowledge acquired or generated (Zaied et al., 2012). The application of knowledge is one of the objectives of knowledge management and the most prominent operations, and this process includes the use of terms specific to knowledge such as: use, reuse, utilization, and application (Dalkir, 2005).

\subsubsection{Technology Knowledge}

Technology knowledge refers to the means, methods and actions used to convert organizational inputs into outputs. It refers to the most significant developments in information technology that have contributed to the emergence and development of knowledge management, such as knowledge work systems, knowledge-based decision support systems. Information technology can store human intelligence and experience, such as databases, software, etc., but it cannot store the sensory meaning of the parts of data stored in the minds of individuals. Technology is therefore only a tool to facilitate knowledge management.

\subsubsection{Organization effectiveness}

The concept of effectiveness is essentially based on doing the right thing. Effectiveness should be based on clear, impartial and fair objectives. Griffin (1999) supports this view in his definition of organizational effectiveness by pointing out that it is the planning and preparation for doing the right things. Organizational effectiveness is the degree to which the organization achieves its objectives (Daft, 2001; Muslim et al., 2019). It is the ability of an organization to exploit the opportunities of its environment to access scarce and valuable resources to perform its function (Hall, 1992). Jones (2001) links organizational effectiveness to the extent to which an organization can meet and achieve stakeholder goals. Organizational effectiveness is the continuous success in achieving the mission of the organization (Kushner, 2006). Organizational effectiveness is the 
measurement of the extent to which the objectives or degree to which management can control organizational and environmental conditions in order to provide the products expected by the community and external entities (Isoraite, 2005). Organizational effectiveness is the ability of the organization to produce more and higher quality, and its ability to adapt effectively to the surrounding environmental problems (Basol \& Dogerlioglu, 2014). It is the ability of the organization to mobilize power centers for efficient production and adaptation to environmental and internal problems (Schriesheim \& Eisenbach, 1995. Organizational effectiveness is the ability of the organization to manage its internal operations along with taking benefit from its internal and external environment, acquire scarce resources and exploit them in order to achieve the objectives of the organization (Sadq et al., 2019).

\subsection{The significance of organizational effectiveness}

1. It increases the organization's ability to achieve its objectives by making better use of its available resources (Robbins, 1998).

2. It can promote the achievement of goals since it is the key to the initiative to succeed by adopting a final measure of a successful initiative (Kerr and Lanaduer, 2004).

3. Active organization meaning the organization is characterized by the high performance of its workers (Esfahani, et al., 2013).

4. It increases the ability of the organization to formulate its strategy in such a way that it can exploit the opportunities available and avoid the threats it faces. Ultimately, to strengthen its strengths and overcome its weaknesses (Robbins, 1998).

\section{Methodology of the study}

The study adopted the descriptive analytical method to collect the necessary information as follows. Firstly, primary sources based on the data collected from the study sample through a questionnaire was prepared for this purpose. Secondary sources were used to cover the theoretical aspect of this study such as books and related scientific studies. The questionnaire used as a tool to collect primary data consists of two sections. The first section contains (30) end-closed question aimed at identifying managers' attitudes towards the adoption of private banks in the Kurdistan Region of Iraq to the concept of knowledge management. Section two contains (10) end-closed question to identify the level of organizational effectiveness felt by the respondents. The questionnaire is based on the Five- Likert scale: strongly agree (5), agree (4), uncertain (3), disagree (2), and strongly disagree (1). The statistical program (SPSS) was used to analyze the questionnaires through various statistical analysis. The study population consists of all managers in the private banks in Kurdistan Region of Iraq. In the Erbil city there are 42 private banks. The researcher distributed the questionnaire to a (80) managers and supervisors and (76) were returned, however (69) forms was suitable for analysis. In light of the problem of the study and its objectives, the following model has been proposed to diagnose the impact of knowledge management on organizational effectiveness as shown in Fig. 1.

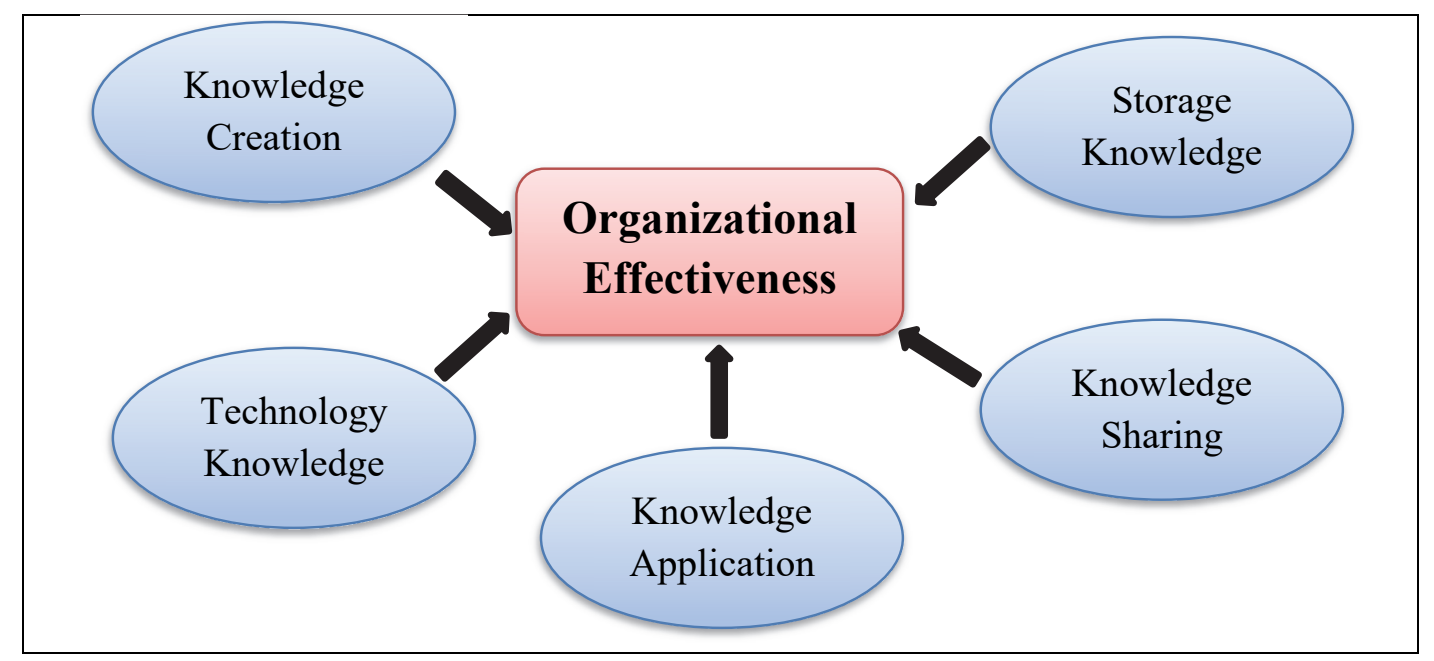

Fig. 1. study model

The study model was built in light of the review of relevant literature. The independent variable "Knowledge Management" has been based on some recent studies (Zaied et al. 2012; Chang \& Chuang, 2011; Rašula et al., 2012; Liao \& Wu, 2009). However, organizational effectiveness has been based on Sadq et al. (2019). The model assumes an impact of knowledge management through its elements (knowledge creation, storage knowledge, knowledge sharing, knowledge application, and technology knowledge) as an independent variable, on organizational effectiveness as a dependent variable. 


\section{Results}

\subsection{Scale Validity and Reliability}

Modeling approach of structural equation (SEM) was used to test the model. The method is recognized for its utility in testing both the accuracy and validity of the survey-tracked and applied measures. While the conceptual model type is relatively complex, a SEM-PLS approach was also used through bootstrapping procedure in a 2000 sub-sample of the SEM-PLS software (Othman et al., 2019a). In order to use modeling structural equations, it is essential to check the validity of each latent variable and to do so, using the Confirmative Factor Analysis (CFA), the relevant factors are raised. Then we have to check the "validity of discrimination" and the "validity of convergence". In order to test the first step, according to Ramdé et al. (2012), we examined the Average Variance Extracted (AVE) and factor loadings that must always be greater than 0.5. The AVE root must be linked to all factors while at the same time confirming the validity of discrimination based on the criteria given (Othman et al., 2019b). In addition, when using the "structural equation model", the "composite reliability" must exceed 0.70 and the reliability of the latent variable is confirmed by helping Cronbach's $\alpha$ to exceed the recommended 0.6 threshold (Sarstedt et al., 2014).

\subsection{Measurement Model}

According to Table 1, the latent variables are categorized by the "convergence validity" of all loading factors and for all study variables, the value of (AVE) is higher than 0.5 and for all latent variables, the CR values are higher than the 0.7 criteria, showing that the qualified components maintain good reliability. However, using the reliability measure; namely Cronbach's $\alpha$, all latent values were greater than 0.6 , and this evidence is sufficient to determine that the study content is accurate. While reviewing the validity of discrimination, Table 2 shows that AVE root square values are greater than inter-structure correlations for all variables. We can therefore conclude that the measurement model has good reliability and its validity to indicate the study variables is constructive and reliable.

Table 1

Variables Measurement Model

\begin{tabular}{ccccc}
\hline & Cronbach's Alpha & rho A & Composite Reliability & Average Variance Extracted (AVE) \\
\hline KA & 0.765 & 0.772 & 0.852 & 0.908 \\
KC & 0.865 & 0.868 & 0.917 & 0.713 \\
KS & 0.887 & 0.888 & 0.844 & 0.690 \\
OE & 0.754 & 0.755 & 0.923 & 0.576 \\
SK & 0.898 & 0.924 & 0.818 & 0.707 \\
TK & 0.703 & 0.701 & 0.530 \\
\hline Note: KA $=$ Knowledge Application; KC= Knowledge Creation; KS= knowledge sharing; & OE= Organizational Effectiveness; SK= Storage Knowledge;
\end{tabular}

Note: $\mathrm{KA}=$ Knowledge Application; $\mathrm{KC}=$ Knowledge Creation; $\mathrm{KS}=$ knowledge sharing; $\quad$ OE= Organizational Effectiveness; SK= Storage Knowledge; $\mathrm{TK}=$ Technology Knowledge.

Table 2

Discriminant Validity of Latent Constructs

\begin{tabular}{|c|c|c|c|c|c|c|}
\hline & KA & $\mathrm{KC}$ & KS & $\mathrm{OE}$ & SK & TK \\
\hline KA & 0.770 & & & & & \\
\hline $\mathrm{KC}$ & 0.666 & 0.844 & & & & \\
\hline KS & 0.673 & 0.603 & 0.831 & & & \\
\hline $\mathrm{OE}$ & 0.608 & 0.611 & 0.556 & 0.759 & & \\
\hline SK & 0.597 & 0.589 & 0.526 & 0.619 & 0.841 & \\
\hline TK & 0.609 & 0.688 & 0.532 & 0.551 & 0.464 & 0.728 \\
\hline
\end{tabular}

Note: $\mathrm{KA}=$ Knowledge Application; $\mathrm{KC}=$ Knowledge Creation; $\mathrm{KS}=$ knowledge sharing; $\mathrm{OE}=$ Organizational Effectiveness; SK= Storage Knowledge; $\mathrm{TK}=$ Technology Knowledge.

\subsection{Path Coefficients}

The researcher conducted tests of bootstrapping with 2000 resampling to derive the significance test of t-values structural paths. To do this, the path coefficient is significant if the t-test is higher than 1.96 because a 5 percent two-tailed test is used by the meaning level (Hair et al., 2014). Table 3 displays the results.

Table 3

Hypothesis results

\begin{tabular}{lrrrrr} 
& Original Sample $(\mathrm{O})$ & Sample Mean $(\mathrm{M})$ & Standard Deviation (STDEV) & T Statistics $(|\mathrm{O} / \mathrm{STDEV}|)$ & $\mathrm{P}$ Values \\
\hline $\mathrm{KA} \rightarrow \mathrm{OE}$ & 0.150 & 0.148 & 0.055 & 2.752 \\
$\mathrm{KC} \rightarrow \mathrm{OE}$ & 0.159 & 0.158 & 0.058 & 2.740 \\
$\mathrm{KS} \rightarrow \mathrm{OE}$ & 0.121 & 0.122 & 0.049 & 0.006 \\
$\mathrm{SK} \rightarrow \mathrm{OE}$ & 0.305 & 0.309 & 0.049 & 0.013 \\
$\mathrm{TK} \rightarrow \mathrm{OE}$ & 0.144 & 0.145 & 0.064 & 0.186 \\
\hline
\end{tabular}

Note: $\mathrm{KA}=$ Knowledge Application; $\mathrm{KC}=$ Knowledge Creation; KS= knowledge sharing; $\mathrm{OE}=$ Organizational Effectiveness; SK= Storage Knowledge; $\mathrm{TK}=$ Technology Knowledge. 
The findings suggest that variables such as the knowledge application $(\beta=0.150, \mathrm{p} \leq 0.05)$, knowledge creation $(\beta=0.159$, $\mathrm{p} \leq 0.05)$, knowledge sharing $(\beta=0.121, \mathrm{p} \leq 0.05)$, storage knowledge $(\beta=0.305, \mathrm{p} \leq 0.05)$, technology knowledge $(\beta=0.144$, $\mathrm{p} \leq 0.05)$ have positive and significant effects on organizational effectiveness. Results from the output of Smart-PLS also show support for all hypotheses. The positive impact on customer based on the results implied the positive and significant impact of the knowledge management on organizational effectiveness.

For academic researchers, the study suggests some implications. This gives the relationship between organizational effectiveness and knowledge management a clear and profound underestimation. Although some studies have also conducted questions about the separation of information management and relationships of organizational effectiveness, the areas such as private banks together has not been investigated. In addition, this study targeted the region of Iraqi Kurdistan, where there was a lack of such contribution in the banking sector. The outcome and suggestion of this study will be very helpful for various practitioners in the banking sector as well as directors, managers and staff members as there is still an evolving stage in the banking sector. To achieve sustainable growth and competitive edge over others, Private Banks need to concentrate more on their customer satisfaction, which leads a customer to loyalty as shown in the study result. Such results also have great importance in designing multiple approaches, policies and proposals for banking sectors for policymakers and various high-level authorities.

\section{Discussion and Conclusion}

The study has shown that the private banks in the Erbil city adopt the application concept of knowledge management from the attitude of its managers and supervisors. The dimensions of knowledge management that were studied can be ranked according to their relative importance as: storage knowledge, knowledge sharing, knowledge creation, storage knowledge, and technology knowledge. Knowledge is power in today's era of competitive advantages, and if it captures the knowledge management tools it can be easily used to its advantage to empower organizations and achieve organizational effectiveness. Furthermore, the study has shown that organizational effectiveness is a goal and a tool. As a goal, it is a necessary phenomenon to ensure the long-term viability of the organization. It is also the main tool to help organizations achieve their goals and outcomes. It is important to emphasize that there are clear differences among organizations in terms of size, type, sector or objective. Therefore, elements or criteria for measuring effectiveness in one organization may not be applicable for another organization. This requires careful attention when selecting each organization for the criteria that will be used to measure its effectiveness.

\section{Recommendations}

The private banks should adopt the knowledge management in a logical sequence that contributes in achieving an organizational environment supportive of an enabling environment up to the practice of radical changes. It is important to build an organizational culture based on cooperation between employees, and encouraging the exchange of knowledge in order to reach the learning organization characterized by the fact that much of its core knowledge is internal, and that its management and staff learn from their experiences. Improving the work organizational climate through providing a comfortable working environment for employees and delegating sufficient powers to enable them to apply their knowledge. Involving employees in policy-making and decision-making related to their work could increase their morale, improve performance and enable organizations to retain their best competencies.

\section{References}

Akdere, M. (2009). The role of knowledge management in quality management practices: Achieving performance excellence in organizations. Advances in Developing Human Resources, 11(3), 349-361.

Alavi, M., Kayworth, T.R. \& Leidner, D.E. (2005) An empirical examination of the influence of organizational culture on knowledge management practices. Journal of Management Information Systems, 22(3), 191-224.

Albream, F \& Maraqa, M. (2019). The impact of adopting e-collaboration tools on knowledge management processes. Management Science Letters, 9(7), 1009-1028.

Arazpoor, S., \& Meymand, M. (2016). Identifying the effective factors on customer knowledge management development: Evidence from customs industry. Management Science Letters, 6(1), 25-30.

Basol, E., \& Dogerlioglu, O. (2014). Structural determinants of organizational effectiveness. Journal of Organizational Management Studies, Article ID 273364,

Bishop, J., Bouchlaghem, D., Glass, J., \& Matsumoto, I., (2008). Ensuring the effectiveness of a knowledge management initiative. Journal of Knowledge Management. 12(4), 16-29.

Bourdreau, A. \& Couillard, G. (1999). Systems integration and knowledge management. Information Systems Management, 16(4), 24-32.

Bukowits, W. \& Williams, R. (2000). The Knowledge Management FieldBook. London, U.K.: Pearson Education Ltd.

Chang, T.C., \& Chuang, S.H. (2011). Performance implications of knowledge management processes: Examining the roles of infrastructure capability and business strategy. Expert Systems with Applications, 38(5), 6170-6178.

Coakes, E. (2003). Knowledge Management: Current Issues and Challenges. Idea Group Publishing, Hershey. 
Daft, R. L. (2007). Understanding the Theory and Design of Organization. Mason, OH: Thomson South-Western.

Daft, R. L., (2001). Organization Theory and Design. $7^{\text {th }}$ ed., South-Western College Publishing, Ohio.

Dalkir, K. (2005). Knowledge Management in the Theory and Practice. Elsevier Butterworth, Heine Mann, U.S.A.

Darling, M. S. (1996). Building the Knowledge Organization, Business Quarterly, 61(2), 61-66.

Esfahani, A. N., Hosseini, M.., Fanaei., H., \& Azam, M. (2013). Evaluate the effectiveness of group work and development of methods on Esfahan group work gas. International Journal of Academic Research in Business and Social Sciences, 3(11) 531-548.

Ghomi, H., \& Barzinpour, F. (2018). Identifying the success factors of knowledge management tools in research projects (Case study: A corporate university). Management Science Letters, 8(8), 805-818.

Griffin, R. (1999). Management. $6^{\text {th }}$ ed. Boston, Houghton Mifflin.

Hall, R. H., (1992). Organizations Structure and Process: Process and Outcomes. $5^{\text {th }}$ ed., Prentice Hall of India Private Limited, New Delhi.

Harun, A., Mahmud, M., Othman, B., Ali, R., \& Ismael, D. (2020). Understanding experienced consumers towards repeat purchase of counterfeit products: The mediating effect of attitude. Management Science Letters, 10(1), 13-28.

Išoraite, M. (2005). Evaluating efficiency and effectiveness in transport organizations. Transport, 20(6), 240-247.

Jamil, R., \& Lodhi, M. (2015). Role of knowledge management practices for escalating universities' performance in Pakistan. Management Science Letters, 5(10), 945-960.

Jashapara, A. (2004). Knowledge Management an Integrated Approach. England, Prentice Hall.

Jones, G., R. (2001). Organizational Theory: Text and cases, $3^{\text {rd }}$ ed., prentice -Hall, N.J.

Kerr, S., \& Landauer, S. (2004). Using stretch goals to promote organization effectiveness and personal growth: General Electric and Goldman Sachs. Academy of Management Executive, 6(18) 134-138.

Kushner, R.J. (2006). Facilitators guide for assessing organizational effectiveness in national societies: a resource for organizational development facilitators in the international Red Cross. Red Crescent Movement. International Services Department: Technical Assistance, Planning and Evaluation Unit. Washington, DC.

Laudon, K., \& Laudon, J. (2005). Management Information Systems: Managing Digital Firm. Prentice Hall Inc., New Jersey. U.S.A.

Liao, S.H. \& Wu, C.C. (2009). The relationship among knowledge management, organizational learning, and organizational performance. International Journal of Business and Management, 4(4), 64-76.

Lin, H.-F. (2007). Effects of extrinsic and intrinsic motivation on employee knowledge sharing intentions. Journal of Information Science, 33(2), 135-149.

Manab, N \& Aziz, N. (2019). Integrating knowledge management in sustainability risk management practices for company survival. Management Science Letters, 9(4), 585-594.

Martins, K., Hiesig, P., \& Varbeck, J., (2001). Knowledge Management Best Practices in Europe. Springer-Verlay Berlin Heidelberg.

Mathew, V. (2008). Knowledge management progression, issues and approaches for organizational effectiveness in manufacturing industry: An implementation agenda. The ICFAI Journal of Knowledge Management, 6(1), 20-45.

Muslim, A., Harun, A., Ismael, D., \& Othman, B. (2020). Social media experience, attitude and behavioral intention towards umrah package among generation X and Y. Management Science Letters, 10(1), 1-12.

Norang, A., \& Nooshin, S. (2016). Identifying different methods for creating knowledge from lessons learned in project oriented organizations. Management Science Letters, 6(1), 19-24.

Othman, B., Harun, A., Rashid, W., Nazeer, S., Kassim, A., \& Kadhim, K. (2019a). The influences of service marketing mix on customer loyalty towards Umrah travel agents: Evidence from Malaysia. Management Science Letters, 9(6), 865-876.

Othman, B., Harun, A., Rashid, W., \& Ali, R. (2019b). The impact of Umrah service quality on customer satisfaction towards Umrah travel agents in Malaysia. Management Science Letters, 9(11), 1763-1772.

Ping, L., Jing, X., Othman, B., Yuefei, F., Kadir, Z. B. A., \& Ping, X. (2019). An Intercultural Management Perspective of Foreign Student's Adaptation in Chinese Universities: A Case Study of China Three Gorges University. Engineering, Technology \& Applied Science Research, 9(2), 3971-3977.

Ramdé, J. (2012). Utilisation des connaissances issues de la recherche en éducation Validation d'un questionnaire et proposition d'un modèle.

Rao, M.S. (2012). Knowledge management: Some issues and challenges for corporate excellence in the 21 st century. IOSR Journal of Business and Management (IOSRJBM), 1(2), 01-03.

Rašula, J., Vukšić, V.B., \& Štemberger, M.I. (2012). The impact of knowledge management on organisational performance. Economic and Business Review, 14(2), 147-168.

Robbins, S. P. (1998). Organization Behavior: Concepts Controversies \& Application, $8^{\text {th }}$ ed., N.J: Prentice - Hall, Inc.

Sadq, Z. M., Sabir, H. N., Sulaiman, V., \& Saeed, H. (2018). Analyzing the amazon success strategies. Journal of Process Management - New Technologies, International, 6(4), 65-70.

Sadq, Z.M., Aljaf, N.A. \& Hasan, R.S. (2018). The role of human capital in achieving competitive advantages: An empirical study at knowledge private university /Erbil, Iraq. International Journal of Social Sciences \& Educational Studies, 4(4), 53-63.

Sadq, Z.M., Ahmad, B.S., \& Jwmaa, S.J. (2019). The role of empowerment strategies in achieving organizational effectiveness (An Analytical Study of Managers' Views in a Sample of Private Banks in Erbil/ Iraq). International Journal of Social Sciences \& Educational Studies. 5(3), 110-127. 
Sadq, Z. M., Othman, B., \& Khorsheed, R. K. (2019). The impact of tourism marketing in enhancing competitive capabilities. African Journal of Hospitality, Tourism and Leisure, 8(5), 1-11.

Sarstedt, M., Ringle, C. M., \& Hair, J. F. (2014). PLS-SEM: Looking back and moving forward. Long Range Planning, $47(3), 132-37$

Schriesheim, C., \& Eisenbach, R. J. (1995). An exploratory and confirmatory factor-analytic investigation of item wording effects on the obtained factor structures of survey questionnaire measures. Journal of Management, 21(6), 1177-1193.

Segev, E. (2010). Mapping Knowledge into a Database Model. Journal of Knowledge Management Practice, 11(1).

Song, M., van der Bij, H., \& Weggeman, M. (2006). Factors for improving the level of knowledge generation in new product development. R\&D Management, 36(2), 173-187.

Turban, E., McLean, E., \& Wetherbe, J. (2004). Information Technology for Management. $4^{\text {th }}$ ed., John Wiley \& Sons, New York.

Wiig, K.M. (1993). Knowledge Management Foundations: Thinking about Thinking. Arlington Texas: Schema Press.

Zaied, A. N. H., Hussein, G. S., \& Hassan, M. M. (2012). The role of knowledge management in enhancing organizational performance. International Journal of Information Engineering and Electronic Business, 4(5), 27.

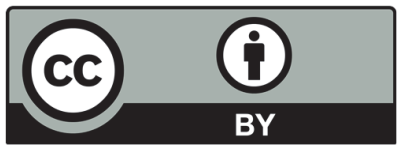

(C) 2020 by the authors; licensee Growing Science, Canada. This is an open access article distributed under the terms and conditions of the Creative Commons Attribution (CC-BY) license (http://creativecommons.org/licenses/by/4.0/). 